\title{
Chemical and physical attributes of five Oxisols as predictors of shoot dry mass of white oats ${ }^{1}$
}

\author{
Renato Teodoro de Lima ${ }^{2}$ (D), Cezar Francisco Araujo-Junior ${ }^{3}$, Mario Miyazawa ${ }^{3}$
}

10.1590/0034-737X202168050009

\begin{abstract}
In no-tillage systems, oats are one of the species most used as a cover crop in the subtropical region of Brazil. This study aims is to determine a set of chemical and physical properties of five Oxisols after surface liming, and to determine whether these properties are related to the shoot dry mass production of white oat (Avena sativa L.) variety IPR Aphrodite, in order to establish a model to predict its yield. For this purpose, a field experiment was conducted during 2015 and 2016 in Londrina County in the State of Paraná with samples of B horizon collected from five Oxisols with clay content ranging from 15-80 dag kg-1 arranged in microplots since 2004. Soil pH in $\mathrm{CaCl}_{2}$, calcium, magnesium, potassium, potential cation exchange capacity (CEC), base saturation, microporosity, total porosity, field capacity, permanent wilting point, clay and sand of the Oxisols were the parameters that most influenced the dry mass production of white oats. Oxisol extrinsic factors such as values $\mathrm{pH}$ and base saturation, as well as the calcium and magnesium contents, positively altered with surface liming, boosting the production of oat dry mass production.
\end{abstract}

Keywords: Avena sativa L.; IPR Afrodite; no-tillage system; cover crop; soil acidity.

\section{INTRODUCTION}

Oat is one of the species most used as a cover crop within the southern region of Brazil , and this use is related to this plant's carbon and nitrogen ratio, high root volume and deep rooting in the soil profile (Muzilli, 2002). This species produces high shoot dry mass, which provides adequate protection of the soil surface because of its hardiness and tillering capacity (Ziech et al., 2015). In addition, graniferous white oats are used for human and animal consumption, with the grains, silage, pre-dried silage and hay (Oliveira et al., 2018) being used.

The white oat variety IPR Afrodite represents an efficient economical contribution to the production chain with probably high gians for growers (Riede et al., 2015). In addition, these authors point out that the food industry is furnished with high-quality grains for process several derivatives of this cereal, whereas shoppers have access to merchandise with higher quality, uniformity and flavour. In addition to food industry applications, IPR Afrodite white oats may be useful for conservation production systems by providing soil surface cover against raindrop impact and hydric erosion and by playing an important role in nematode management. In a greenhouse experiment, the white oat variety IPR Afrodite showed important role for nematode management which was found to be highly resistant to species of the genus Meloidogyne but moderately susceptible to the nematode Pratylenchus brachyurus (Riede et al., 2015).

In a long-term no-tillage trials for evaluating soybean cropping systems in a Argissolo Vermelho Distrófico/ Ultisol with sandy texture ( $86 \mathrm{dag} \mathrm{kg}^{-1}$ of sand) in Umuarama County in northwestern Paraná (PR) state, Brazil, Bordin et al. (2020) verified that white oat is the best choice to precede soybean for increasing grain yield.

In the state of Paraná, to neutralize soil acidity in the no-tillage system, surface liming without mechanical limestone incorporation is recommended. (Oliveira \& Pavan, 1996). In an Oxisol in Ponta Grossa, PR, Caires et al. (2006) observed that surface liming did not promote increases in black oat dry mass production. In contrast,

\footnotetext{
Submitted on August 27th, 2019 and accepted on March 29th, 2021.

${ }^{1}$ This work is part of the first author Master's dissertation.

${ }^{2}$ Universidade Federal do Paraná, Curitiba, Paraná, Brazil. renatoteodoroagro@bol.com.br

${ }^{3}$ Instituto de Desenvolvimento Rural do Paraná, IAPAR - EMATER (IDR - Paraná), Londrina, Paraná, Brazil. cezar_araujo@idr.pr.gov.br; miyazawaiapar@gmail.com

*Corresponding author: renatoteodoroagro@bol.com.br
} 
Soratto \& Crusciol (2008) found that in dry years, surface liming increased the grain yield of black oats. In addition, vegetable extracts from oats can assist in the mobility of basic cations at depths in the soil and can also soften the exchangeable $\mathrm{Al}$ of the soil (Diehl et al., 2008).

Oat cultivation is traditionally used to adapt to a large vary of soil that change in chemical and physical attributes (Sorrells \& Simmons, 1992). It is therefore important to know which soil attributes exert the greatest influence on the production of oats, thus helping in the management of the crop and in predicting its productivity. In a Cambissolo/Inceptisol in southern Brazil, Andognini et al. (2020) noted decrease in the dry mass of black oats with increasing soil compaction. On the other hand, in a Latossolo Vermelho Distroférrico/Oxisol cultivated with soybean on a common-black oat straw, Balbinot Junior et al. (2020) pointed out that oat root and shoot dry mass contributed to greater availability of water for soybean plants during water-deficit periods.

Oxisols represent the most common soil order in Brazil, constituting more than $50 \%$ of the arable area. In Paraná, Oxisols occupy approximately 30\% (Bhering \& Santos, 2008).

When using agrometerological models to estimate crop productivity, data collected from meteorological stations are usually used, which have limitations regarding the spatial representativeness of the results (Junges \& Fontana, 2011). Simulating oat productivity in Rio Grande do Sul, Marolli et al. (2017) developed a mathematical model that showed efficiency in simulating the oat grain yield through meteorological parameter like thermal sum, radiantion and precipitation, nitrogen fertilization and growth regulator.

Chemical and physical attributes of the soil can directly influence crop production, thus being able to integrate models in the production estimate. (Affholder et al., 2013).

Grain yield of the commercial variety Pérola showed positive linear correlation with aggregates indexes, microorganism biomass carbon and total soil organic carbon content of a Latossolo Vermelho Distrófico (Rhodic Haplustox) submitted to a no-tillage and these soil attributes along r explained $49 \%$ of variability (Stone $e t$ al., 2013).

Consideration of an isolated soil attribute as a determinant in crop production can generate errors due to the interrelationships among the attributes (Vezzani \& Mielniczuk, 2009; Stone et al., 2013). Our hypothesis is that the shoot dry mass of white oat will be foretold from soil chemical and physical attributes. So, this study aims to identify a set of chemical and physical soil attributes and to correlate them with the shoot dry mass of white oat variety IPR Afrodite to analyse the result of surface liming on the cultivation of this grass in five Oxisols.

\section{MATERIALAND METHODS}

The study was conducted in Londrina County, in northern Paraná, in southern Brazil, in microplots at the Research Station of the Rural Development Institute of Paraná, IAPAR - EMATER (IDR-Paraná) at latitude $23^{\circ}$ $21^{\prime} 30^{\prime \prime} \mathrm{S}$ and line longitude $51^{\circ} 10^{\prime} 17^{\prime \prime} \mathrm{W}$ and at a mean altitude of $570 \mathrm{~m}$ higher than sea level (Nitsche et al., 2019). In 2004, B horizon samples from Oxisols from different sites in the state of Paraná (Londrina, Mauá da Serra, Arapongas and Ponta Grossa) (Figure 1) were collected and classified according to the Brazilian Soil Classification System (SiBCS) (Empresa Brasileira de Pesquisa Agropecuária - EMBRAPA, 2018) besides the equivalence for Soil Taxonomy. These locations were selected because their soils exhibit a wide range in particle size distribution and consequently distinct chemical and physical attributes.

Oxisols in the current study were classified into: LAd, Latossolo Vermelho Distrófico (Rhodic Haplustox) - Pon-

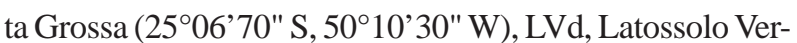

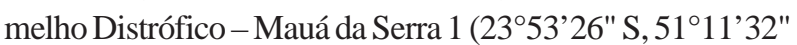
W); (LVAd, Latossolo Vermelho-Amarelo Distrófico (Typic

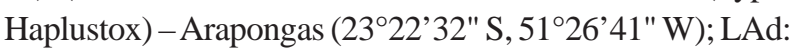
Latossolo Amarelo Distrófico (Typic Haplustox) - Mauá

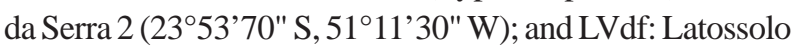
Vermelho Distroférrico (Rhodic Hapludox) - Londrina (2311'19" S, 51 $\left.09^{\circ} 19^{\prime \prime} \mathrm{W}\right)$.

In 2004, samples were collected from the B horizons of five Oxisols from different counties in Paraná (Figure 1) and conditioned on microplots with dimensions $10 \mathrm{~m}$ length by $1 \mathrm{~m}$ width and $0.7 \mathrm{~m}$ in depth in an open system (Figure 2). For the experiments conducted between 2004 and 2017, the plots were subdivided into microplots with dimensions $2 \mathrm{~m}$ length per $1 \mathrm{~m}$ width (Figure 2), in parallel bands with a factorial scheme $(5 \times 3 \times 3+1)$. Three winter crops were grown on microplots; however, in the present study, only white oat cultivar IPR Afrodite was cultivated, with three replicates with additional treatment fallow plots in each soil class to study the effects of conservation practices of crop succession and liming in different soil classes on crop yield according to procedures described by Bertoni \& Lombardi Neto (2010).

With the application of dolomitic limestone on a surface without mechanical incorporation on April 12, 2004 it was sought to neutralize $100 \%$ of the potential acidity $(\mathrm{H}+\mathrm{Al})$ of the soil. From 2004 to 2011, during autumn and winter, plots with wheat, forage turnip and a mixture of black oat (A. strigosa Schreb) cultivar IAPAR-61 Ibiporã + radish (Raphanus sativus L.) + common vetch (Vicia sativa $\mathrm{L}$.) were established in all soil classes. In addition, in the summers, soybean was grown. From 2011 to 2014, in autumn and winter, the beds remained fallow, and maize 
was grown in the summers. For both periods, the notillage system was used.

Soil samples with preserved and unpreserved structure were collected on June 4, 2015, at depths of $0-0.10$ and $0.10-0.20 \mathrm{~m}$. Disturbed soil samples were dried at $60^{\circ} \mathrm{C}$ during a forced oven for 48 hours and disaggregated to undergo a 2-mm sieve.
The samples were sent to the Laboratory of Soils and Plant Tissue of IAPAR-Londrina, PR, for determination of the $\mathrm{P}$ (Mehlich), total organic carbon (by the wet combustion method) (Walkley \& Black, 1934). Through atomic absorption spectrophotometry, exchangeable calcium $(\mathrm{Ca})$, magnesium $(\mathrm{Mg})$ and aluminum $(\mathrm{Al})$ were determined, which were extracted with $1 \mathrm{~mol} \mathrm{~L}^{-1} \mathrm{KCl}$ during a 1:10 soil: solution. Soil

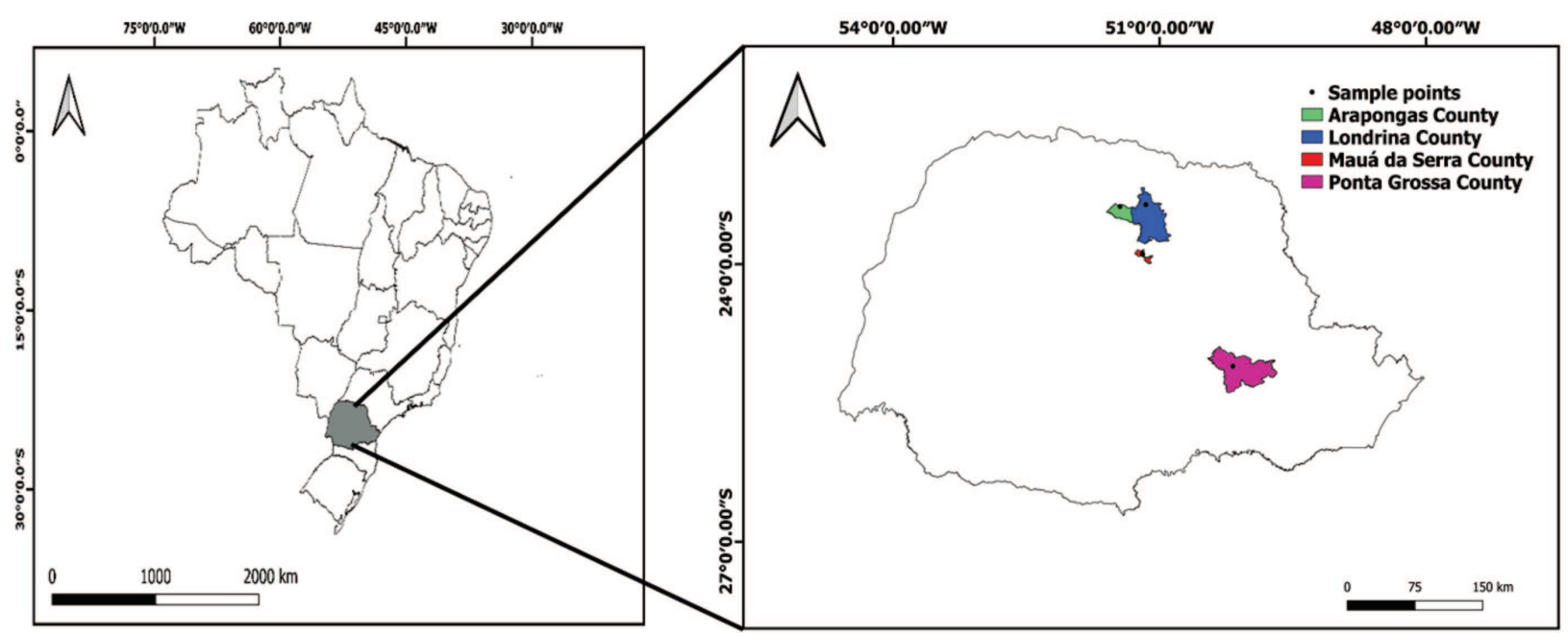

Figure 1: Map of the state of Paraná identifying the locations where the soil samples were collected in 2004 to construct field microplots in an open system.

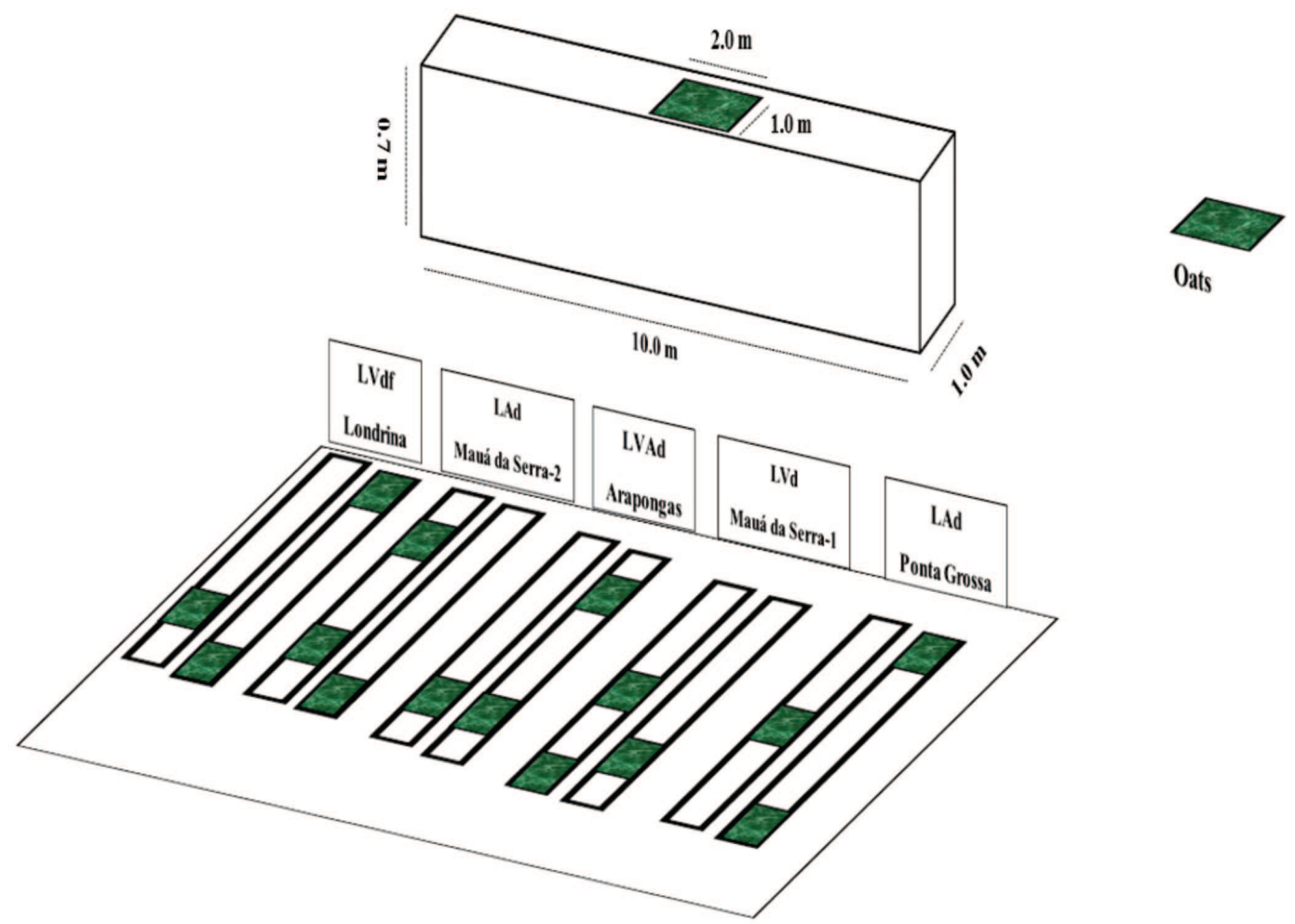

Figure 2: Experimental scheme of 15 plots cultivated with white oats in five soil classes in the state of Paraná. LVdf Londrina: Latossolo Vermelho Distroférrico (Rhodic Hapludox) of the Londrina County; LAd: Latossolo Amarelo Distrófico (Typic Haplustox) of the Maúa da Serra; LVAd: Latossolo Vermelho-Amarelo Distrófico(Typic Haplustox) of the Arapongas County; LVd: Latossolo Vermelho Distrófico (Rhodic Acrustox) and Lad Ponta Grossa: Latossolo Amarelo Distrófico (Typic Haplustox) of the Ponta Grossa County. White rectangle is the microplot. Green squares represents microplots cultivated with white oat cultivar IPR Afrodite. 
$\mathrm{pH}$ was determined at $0.01 \mathrm{~mol} \mathrm{~L}^{-1} \mathrm{CaCl}_{2}$ in during a 1:2.5 soil: solution ratio; $\mathrm{K}$ (Mehlich). A mixture of sulfuric and hydrochloric acid $\left(\right.$ Mehlich $\left.^{-1}\right)$ was used to determine the available phosphorus and potassium contents. The determination of all chemical attributes of the soil were carried out according to the reference procedure used by IAPAR and described by Pavan et al. (1992).

The pipette method (Day, 1965) was used to carry out the textural analysis of the soil, using sodium hydroxide $\left(\mathrm{NaOH}-0.1 \mathrm{~mol} \mathrm{~L}^{-1}\right)$ as a chemical dispersant, and mechanical dispersion was performed with the addition of $20 \mathrm{~g}$ coarse sand and slow stirring for 16 hours (Grohmann \& Raij, 1977) in a reciprocal shaker at 180 cycles/min (Miyazawa \& Barbosa, 2011).

Soil samples with preserved structure were slowly saturated in trays with water up to $2 / 3$ of the height of the ring. Subsequently, they were subjected to matric potentials (-øm): $-2,-4,-6,-8$ and $-10 \mathrm{kPa}$ in an EijkelkampGiesbeek ${ }^{\circledR}$ suction table and $-33,-100,-500$ and $-1,500$ $\mathrm{kPa}$ in Richards Soil Moisture ${ }^{\circledR}$ extractors until they reached equilibrium so that the wet soil mass was determined. To determine the soil bulk density, the samples were taken to a oven at $105-110{ }^{\circ} \mathrm{C}$ for $48 \mathrm{~h}$ to obtain the soil dry mass and calculate the soil bulk density (Grossman \& Reinsh, 2002). Through the product between the gravimetric water content and soil bulk density, the volumetric moisture was obtained (Topp \& Ferré, 2002)..

The soil field capacity (FC) was calculated from the volumetric moisture determined for the $-10 \mathrm{kPa}$ matric potential and permanent wilting point (PWP) or for the residual volumetric water content determined at the $-1,500$ $\mathrm{kPa}$ matric potential. The total porosity, macroporosity and microporosity were determined according to Vomocil (1965) and Flint \& Flint (2002).

The rate of limestone required to raise the base saturation to $70 \%$ was calculated based on the means obtained from the soil chemical analyses at $0-0.20 \mathrm{~m}$ depth. On June 26, 2015, liming was performed with dolomitic limestone (PRNT 77.60\%), which was manually applied to the surface of the beds without physical incorporation into the soil.

In each soil class, three $2 \mathrm{~m} \times 1 \mathrm{~m}$ plots of IPR Afrodite white oats (Avena sativa L.) were established, for a total of 15 plots. The planting furrows were prepared using a handheld rake with $0.05-\mathrm{m}$ prongs, with furrows of approximately $0.03 \mathrm{~m}$ in depth obtained with clearly delimited planting rows spaced $0.17 \mathrm{~m}$ apart. Sowing was done manually on June 27, 2015 (Figure 3), with a sowing density of $98.08 \mathrm{~kg} \mathrm{~h}^{-1}$ being adopted.

Mineral fertilizer was applied to the soil surface between the rows of the crop with the mineral fertilizer formulation 30-04-10 at a dose of $250 \mathrm{~kg} \mathrm{ha}^{-1}$ corresponding to $75 \mathrm{~kg} \mathrm{~N}$ $\mathrm{ha}^{-1}, 10 \mathrm{~kg}$ of $\mathrm{P}_{2} \mathrm{O}_{5}$ ha $^{-1}$ and $25 \mathrm{~kg} \mathrm{ha}^{-1}$ of $\mathrm{K}_{2} \mathrm{O}$. Also under the soil surface between the rows of the crop on July 27, 2015 , top-dressing fertilization with $100 \mathrm{~kg} \mathrm{ha}^{-1}$ of urea, which corresponds to $45 \mathrm{~kg}$ of $\mathrm{N} \mathrm{ha}^{-1}$.

The shoot dry mass yield of white oat was determined on September 18, 2015 (83 days after sowing), when the crop was in a vegetative stage with $50 \%$ flowering (Figure 3 ); to estimate the yield of white oat dry mass, samples were collected from an area of $0.25 \mathrm{~m}^{2}$ per plot, then taken to drying in a forced-air oven at $65^{\circ} \mathrm{C}$ until stable weight was obtained(Hoogmoed \& Derpsch, 1985).

For the statistical analyses, the attributes of the oxisols were considered only for the depth $0-0.10 \mathrm{~m}$. Thus, the data for each attribute originates from three samples of each class of oxisol, totalling 15 samples. In each oxisol studied, the mean, maximum and minimum values were calculated, in addition to the coefficient of variation of the soil attributes; and oat dry mass yield. The same parameters were also calculated for all five oxisols. The attributes of all oxisols were individually correlated with the white oat dry mass yield for all soils.

The model for predicting white oat dry mass production according to the physical and chemical soil attributes was developed through multiple linear regression. However, the presence of multicollinearity may lead to high standard errors, thus preventing any estimations if the multicollinearity is perfect (Gujarati \& Porter, 2011). Factor analysis was performed to solve the problem of multicollinearity by identifying the isolated dimensions of the dataset and then determining the degree to which each variable is explained by each dimension or factor.Soil attributes and white oat dry mass yield were correlated using Pearson's correlation, being used to extract significant attributes at $5 \%$ and $1 \%$ by the $\mathrm{F}$ test.The coefficient of Pearson ( $r$ ) was classified as: (i) $0.00<\mathrm{r}<0.19$, very weak; (ii) $0.20<\mathrm{r}<0.39$, weak; (iii) 0.40 $<\mathrm{r}<0.69$, moderate; (iv) $0.70<\mathrm{r}<0.89$; and (v) $0.90<\mathrm{r}<$ 1.00 , very strong (Gujarati \& Porter, 2011). Bartlett's test of sphericity and Kaiser-Meyer-Olkin (KMO) test were used to analyze these attributes.. Having reached the significance levels for used each test, factor analysis was performed using the Principal Component Analysis, extracting the factors via orthogonal Varimax rotation to obtain the best combinations.

Through the rotated component matrix, a factor load was assigned to each soil attribute relative to the factor. Fifteen factor scores were obtained; that is, composite measurements of each factor computed for each oat dry mass production were obtained, with the original variables being replaced by the factor scores. The linear regression was then performed according to the number of factors extracted, with a linear regression being used if only one factor was extracted, or a multiple regression when two or more factors were extracted. The oat dry mass was 
considered a response variable, and the factor scores for the extracted factors were used as explanatory variables.

To validate the model, it was tested with data obtained for the oxisol attributes evaluated before white oat cultivation and for the dry mass production obtained for the oats in the following year (2016) in the same plots previously described. In the 2016 autumn-winter crop, white oats were cultivated and managed similarly to the previous crop, being sown after soybean cultivation with a new surface application of limestone at the same doses applied to the previous crop (2015).

The efficiency of the model was assessed by the adjusted coefficient of determination $\left(\mathrm{R}^{2}\right)$, root mean square error (RMSE) and mean error (ME).

\section{RESULTS AND DISCUSSION}

The available phosphorus contents in the $0-0.10 \mathrm{~m}$ layer of the Oxisols (Table 1) exceeded the critical value of approximately $11 \mathrm{mg} \mathrm{dm}^{-3}$ for winter cereals (Vieira et al., 2013), except for the lowest value observed in the Latossolo Amarelo Distrófico from Mauá da Serra-2 (Table 1). For the carbon contents of the Oxisols, mean values were low for the Lad, Latossolo Amarelo Distrófico from Mauá Serra-2 and between medium and high for the other soils (Pauletti \& Motta, 2017).
The mean values of $\mathrm{pH}$ in $\mathrm{CaCl}_{2}$ for the Oxisols indicate an average acidity, while the aluminium contents were very low according to criteria described by Pauletti \& Motta (2017). According to these authors, low soil pH values and low alkalinity are the main soil chemical attributes that limit black oat yield in dry winter regions (Table 1).

With regard to the bases, the calcium contents are considered medium in the LAd - Mauá da Serra 2 and high and very high for the other Oxisols. The magnesium content is classified as medium in the LAd - Mauá da Serra 2 and high in the LAd - Ponta Grossa and (LVd, Latossolo Vermelho Distrófico) - Mauá da Serra 1, whereas it is very high in the (LVAd, Latossolo Vermelho Amarelo Distrófico) - Arapongas and (LVdf, Latossolo Vermelho Distroférrico) - Londrina (Pauletti \& Motta, 2017).

Vegetable extracts from oats can assist in depth mobility of lime when applied to the soil surface in a notillage system. Diehl et al. (2008) observed that vegetable extracts of turnip followed by black oats showed higher amounts of water-soluble organic binders, titratable organic acids and organic anions than did extracts from the residues of wheat, corn and soybeans, and these higher values contributed to the ionic mobility of exchangeable bases in soils managed under a conservation production system.

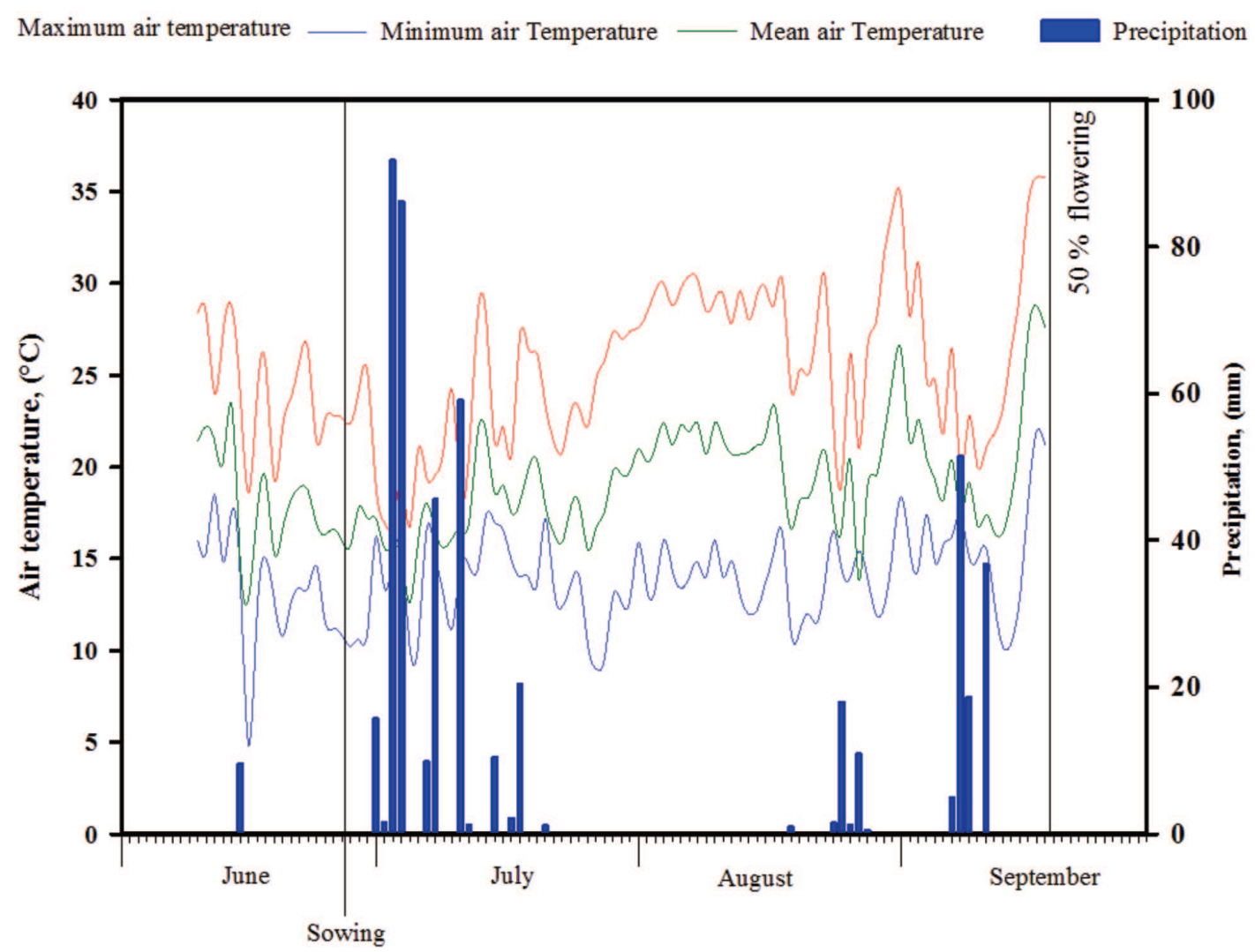

Figure 3: Daily values for maximum, minimum and mean temperatures and for precipitation during the period from June to September 2015, indicating sowing dates and time at 50\% flowering of the white oat crop. Londrina, PR. Source: "Adapted from the Agronomic Institute of Paraná-IAPAR, 2015” 
The mean level of potassium (Table 1) in the oxisols is considered medium in the LAd-Mauá da Serra-2, and LVAd-Arapongas and high in the other soils. The potential CEC indicates low values in the LAd-Mauá da Serra 2 and medium values for the other soils. For base saturation, its mean values are classified as medium in the LAd-Ponta Grossa, LVd- Mauá da Serra 1 and LAd-Mauá da Serra 2 and high in the others (Pauletti \& Motta, 2017).

With regard to all soil classes, soil bulk density averaged $1.16 \mathrm{~g} \mathrm{~cm}^{-3}$ and ranged from 0.94 to $1.53 \mathrm{~g} \mathrm{~cm}^{-3}$ (Table 2). These values are typical for uncompacted Oxisols in Paraná. In the same Oxisols studied here, Araujo-Junior \& Miyazawa (2012), through pedotransfer functions based on a compaction curve obtained through the Proctor test, suggested critical soil bulk density values critical for root growth and crop development in these Oxisols of $1.33 \mathrm{~g} \mathrm{~cm}^{-3}$ (LAd-Ponta Grossa), $1.22 \mathrm{~g} \mathrm{~cm}^{-3}$ (LVd-Mauá da Serra 1), $1.39 \mathrm{~g} \mathrm{~cm}^{-3}$ (LVAd-Arapongas), $1.52 \mathrm{~g} \mathrm{~cm}^{-3}$ (LAd-Mauá da Serra 2) and $1.25 \mathrm{~g} \mathrm{~cm}^{-3}$ (LVdfLondrina). Thus, bulk density values reached critical levels only in the LAd-Mauá da Serra 2. Soil bulk densities below critical values, root development and soil airflow are not are not restricted. In contrast, root growth restrictions are probable for soil bulk densities higher than critical values.

The total soil porosity values were between $0.66 \mathrm{~cm}^{3}$ $\mathrm{cm}^{-3}$ (LVdf-Londrina) to $0.43 \mathrm{~cm}^{3} \mathrm{~cm}^{-3}$ (LVd-Mauá da Serra 2) this difference can be conditioned to textural, mineralogical and structural factors of oxisols. The total porosity of the soil is responsible for the transport and storage of the soil solution and air. Air-filled porosity higher

Table 1: Descriptive statistical measures of the chemical attributes of five Oxisols from the state of Paraná

\begin{tabular}{|c|c|c|c|c|c|c|c|c|c|c|}
\hline \multirow{2}{*}{ Statistic } & \multirow{2}{*}{$\frac{P}{\mathrm{mg} \mathrm{dm}^{-3}}$} & \multirow{2}{*}{$\frac{\text { TOC }}{\mathrm{g} \mathrm{dm}^{-3}}$} & \multirow{2}{*}{ pH } & Al & $\mathbf{H}+\mathbf{A l}$ & $\mathbf{C a}$ & Mg & $\mathbf{K}$ & CEC-T & $\mathbf{V}$ \\
\hline & & & & \multicolumn{6}{|c|}{$\mathrm{cmol}_{\mathrm{c}} \mathrm{dm}^{-3}$} & $\%$ \\
\hline \multicolumn{11}{|c|}{${ }^{1}$ Latossolo Amarelo Distrófico (Typic Haplustox) - Ponta Grossa } \\
\hline Mean & 110.00 & 13.32 & 4.65 & 0.20 & 6.62 & 2.44 & 1.31 & 0.24 & 10.61 & 37.83 \\
\hline Maximum & 134.70 & 14.06 & 4.75 & 0.25 & 7.20 & 2.57 & 1.32 & 0.30 & 11.26 & 39.34 \\
\hline Minimum & 72.30 & 12.03 & 4.60 & 0.14 & 5.97 & 2.30 & 1.31 & 0.19 & 9.77 & 36.06 \\
\hline $\mathrm{CV}(\%)$ & 30.15 & 8.39 & 1.60 & 28.29 & 9.35 & 5.60 & 0.44 & 24.32 & 7.18 & 4.39 \\
\hline \multicolumn{11}{|c|}{ Latossolo Vermelho Distrófico (Rhodic Acrustox) - Mauá da Serra-1 } \\
\hline Mean & 42.67 & 15.05 & 4.93 & 0.01 & 6.05 & 2.76 & 1.59 & 0.30 & 10.70 & 43.39 \\
\hline Maximum & 61.10 & 17.45 & 5.00 & 0.02 & 6.20 & 3.07 & 1.68 & 0.33 & 11.28 & 45.04 \\
\hline Minimum & 23.70 & 12.46 & 4.90 & 0.00 & 5.76 & 2.55 & 1.48 & 0.23 & 10.36 & 40.73 \\
\hline $\mathrm{CV}(\%)$ & 43.84 & 16.62 & 1.17 & 86.60 & 4.20 & 9.85 & 6.34 & 19.46 & 4.72 & 5.36 \\
\hline \multicolumn{11}{|c|}{ Latossolo Vermelho-Amarelo Distrófico (Typic Haplustox) - Arapongas } \\
\hline Mean & 37.07 & 13.82 & 5.20 & 0.06 & 4.86 & 3.45 & 2.18 & 0.15 & 10.64 & 54.37 \\
\hline Maximum & 44.30 & 15.50 & 5.70 & 0.18 & 6.20 & 3.92 & 2.83 & 0.16 & 11.07 & 66.89 \\
\hline Minimum & 24.60 & 12.11 & 4.80 & 0.00 & 3.42 & 2.67 & 1.48 & 0.14 & 10.33 & 41.01 \\
\hline CV (\%) & 29.25 & 12.26 & 8.81 & 173.21 & 28.66 & 19.67 & 31.06 & 7.53 & 3.63 & 23.84 \\
\hline \multicolumn{11}{|c|}{ Latossolo Amarelo Distrófico (Typic Haplustox) - Mauá da Serra-2 } \\
\hline Mean & 17.97 & 6.62 & 5.00 & 0.01 & 3.18 & 1.89 & 0.95 & 0.10 & 6.12 & 47.70 \\
\hline Maximum & 29.40 & 7.48 & 5.20 & 0.04 & 3.42 & 2.25 & 1.11 & 0.12 & 6.58 & 52.35 \\
\hline Minimum & 9.50 & 6.15 & 4.80 & 0.00 & 2.94 & 1.42 & 0.69 & 0.07 & 5.60 & 38.93 \\
\hline $\mathrm{CV}(\%)$ & 57.20 & 11.27 & 4.00 & 173.21 & 7.56 & 22.53 & 24.06 & 26.03 & 8.05 & 15.94 \\
\hline \multicolumn{11}{|c|}{ Latossolo Vermelho Distroférrico (Rhodic Hapludox) - Londrina } \\
\hline Mean & 13.39 & 10.62 & 5.13 & 0.03 & 4.43 & 3.54 & 2.25 & 0.36 & 10.57 & 58.07 \\
\hline Maximum & 14.50 & 11.57 & 5.30 & 0.06 & 4.60 & 3.92 & 2.39 & 0.43 & 11.13 & 60.89 \\
\hline Minimum & 12.58 & 10.09 & 5.00 & 0.00 & 4.08 & 3.15 & 2.09 & 0.30 & 10.14 & 54.64 \\
\hline $\mathrm{CV}(\%)$ & 7.43 & 7.78 & 2.98 & 124.90 & 6.82 & 10.88 & 6.70 & 17.56 & 4.80 & 5.46 \\
\hline \multicolumn{11}{|c|}{${ }^{2}$ All soils } \\
\hline Mean & 44.22 & 11.89 & 4.98 & 0.06 & 5.03 & 2.82 & 1.66 & 0.23 & 9.73 & 48.27 \\
\hline Maximum & 134.70 & 17.45 & 5.70 & 0.25 & 7.20 & 3.92 & 2.83 & 0.43 & 11.28 & 66.89 \\
\hline Minimum & 9.50 & 6.15 & 4.60 & 0.00 & 2.94 & 1.42 & 0.69 & 0.07 & 5.60 & 36.06 \\
\hline $\mathrm{CV}(\%)$ & 88.44 & 28.32 & 5.67 & 140.20 & 27.75 & 27.75 & 35.35 & 46.27 & 19.79 & 19.86 \\
\hline
\end{tabular}

${ }^{1} \mathrm{n}=3$ samples at a depth of $0-0.10 \mathrm{~m} .{ }^{2} \mathrm{n}=15$ samples. P: available phosphorous; TOC: total organic carbon content; $\mathrm{pH}$ : soil $\mathrm{pH}$ determined in $\mathrm{CaCl}_{2} ; \mathrm{Al}$ : aluminium content; $\mathrm{H}+\mathrm{Al}$ : potential acidity; $\mathrm{Ca}$ : calcium content; $\mathrm{Mg}$ : magnesium content; $\mathrm{K}$ : potassium content; $\mathrm{CEC}-\mathrm{T}$ : potential cation exchange capacity; V: base saturation. 
than $0.10 \mathrm{~m}^{3} \mathrm{~m}^{-3}$ have been associated with best soil conditions for plant growth (Xu et al., 1992). (Xu et al., 1992). Macroporosity did not reach critical values in the oxisols (Table 2).

Soil microporosity is related to water storage and clay content, where greater field capacity and permanent wilting point are observed in the soil classes with greater microporosity and clay content, that is, LVd-Mauá da Serra 1 and LVdf-Londrina (Table 2). This relationship is present because these soils have a higher percentage of colloidal material, larger pore spaces and much greater adsorptive surface than soils with a coarser structure (Carvalho et al., 1999).

The selected oxisols vary regarding the particle size composition of the solid particles, with clay content ranging from 11.00 to $81.15 \mathrm{dag} \mathrm{kg}^{-1}$, with very clayey to sandy-loam texture (Table 2).

The shoot dry matter production of the oat cv. IPR Afrodite in the five oxisols of the state of Paraná averaged $4,532.93 \mathrm{~kg} \mathrm{ha}^{-1}$ (Table 2). Among the means, the lowest production was observed in the LAd-Mauá da Serra 2 and the largest in the LVd-Mauá da Serra 1 and LVdfLondrina.

The highest white oat dry mass production was similar to those obtained by the common black oats cultivated in an oxisol from Londrina/PR (Derpsch et al., 1985), where a mean dry mass production of $5,090 \mathrm{~kg} \mathrm{ha}^{-1}$ was obtained. In a study evaluating the dry mass yield of three white oat varieties that were managed at full flowering in an oxisol, Demétrio et al. (2012) obtained a production of 907; 1,185;

Table 2: Descriptive statistical measures of the physical-hydric attributes and dry mass production of white oat shoots in five oxisols of the state of Paraná

\begin{tabular}{|c|c|c|c|c|c|c|c|c|c|c|}
\hline \multirow{2}{*}{ Statistic } & BD & Ma & Mi & TP & FC & PWP & Clay & Silt & Sand & Dry mass \\
\hline & $\mathrm{g} \mathrm{cm}^{-3}$ & \multicolumn{5}{|c|}{$\mathrm{cm}^{3} \mathrm{~cm}^{-3}$} & \multicolumn{3}{|c|}{ dag kg ${ }^{-1}$} & $\mathrm{~kg} \mathrm{ha}^{-1}$ \\
\hline \multicolumn{11}{|c|}{${ }^{1}$ Latossolo Amarelo Distrófico (Typic Haplustox) - Ponta Grossa } \\
\hline Mean & 1.06 & 0.28 & 0.27 & 0.60 & 0.24 & 0.16 & 41.87 & 5.82 & 52.31 & 4099.20 \\
\hline Maximum & 1.09 & 0.29 & 0.28 & 0.60 & 0.25 & 0.16 & 42.70 & 6.95 & 52.54 & 4531.20 \\
\hline Minimum & 1.04 & 0.27 & 0.26 & 0.58 & 0.23 & 0.15 & 40.80 & 5.15 & 52.15 & 3874.80 \\
\hline $\mathrm{CV}(\%)$ & 2.57 & 4.61 & 4.38 & 1.73 & 4.12 & 4.29 & 2.32 & 16.90 & 0.38 & 9.13 \\
\hline \multicolumn{11}{|c|}{ Latossolo Vermelho Distrófico (Rhodic Acrustox) - Mauá da Serra-1 } \\
\hline Mean & 1.01 & 0.28 & 0.34 & 0.64 & 0.31 & 0.23 & 72.70 & 7.62 & 19.68 & 5086.13 \\
\hline Maximum & 1.05 & 0.31 & 0.35 & 0.66 & 0.32 & 0.24 & 73.65 & 8.15 & 20.20 & 5739.20 \\
\hline Minimum & 0.94 & 0.27 & 0.32 & 0.62 & 0.29 & 0.21 & 71.65 & 6.85 & 19.35 & 4713.20 \\
\hline CV (\%) & 5.89 & 8.90 & 5.06 & 3.68 & 6.19 & 7.46 & 1.38 & 8.94 & 2.30 & 11.16 \\
\hline \multicolumn{11}{|c|}{ Latossolo Vermelho Amarelo Distrófico (Typic Haplustox) - Arapongas } \\
\hline Mean & 1.22 & 0.19 & 0.32 & 0.55 & 0.28 & 0.17 & 40.22 & 3.97 & 55.82 & 4853.07 \\
\hline Maximum & 1.24 & 0.21 & 0.33 & 0.56 & 0.28 & 0.17 & 41.35 & 4.95 & 57.95 & 5984.80 \\
\hline Minimum & 1.17 & 0.18 & 0.31 & 0.54 & 0.27 & 0.17 & 38.75 & 3.30 & 54.50 & 3378.40 \\
\hline $\mathrm{CV}(\%)$ & 3.04 & 8.83 & 2.34 & 2.47 & 2.58 & 2.54 & 3.31 & 21.92 & 3.34 & 27.54 \\
\hline \multicolumn{11}{|c|}{ Latossolo Amarelo Distrófico (Typic Haplustox) - Mauá da Serra -2 } \\
\hline Mean & 1.49 & 0.16 & 0.23 & 0.44 & 0.19 & 0.09 & 15.73 & 1.18 & 83.08 & 3596.53 \\
\hline Maximum & 1.53 & 0.18 & 0.26 & 0.45 & 0.21 & 0.09 & 18.85 & 1.75 & 87.25 & 3808.80 \\
\hline Minimum & 1.46 & 0.14 & 0.21 & 0.43 & 0.17 & 0.09 & 11.00 & 0.55 & 80.60 & 3472.80 \\
\hline CV (\%) & 2.59 & 13.25 & 11.80 & 2.56 & 10.53 & 5.31 & 26.49 & 50.94 & 4.37 & 5.13 \\
\hline \multicolumn{11}{|c|}{ Latossolo Vermelho Distroférrico (Rhodic Hapludox) - Londrina } \\
\hline Mean & 1.02 & 0.20 & 0.37 & 0.66 & 0.34 & 0.25 & 80.78 & 10.32 & 8.89 & 5029.73 \\
\hline Maximum & 1.04 & 0.22 & 0.37 & 0.66 & 0.35 & 0.25 & 81.15 & 12.15 & 9.68 & 5446.80 \\
\hline Minimum & 0.99 & 0.17 & 0.36 & 0.65 & 0.33 & 0.24 & 80.40 & 9.30 & 7.45 & 4802.00 \\
\hline CV (\%) & 2.25 & 11.88 & 1.72 & 0.83 & 3.05 & 3.00 & 0.46 & 15.35 & 14.06 & 7.19 \\
\hline \multicolumn{11}{|c|}{${ }^{2}$ All soils } \\
\hline Mean & 1.16 & 0.22 & 0.31 & 0.58 & 0.27 & 0.18 & 50.26 & 5.78 & 43.96 & 4532.93 \\
\hline Maximum & 1.53 & 0.31 & 0.37 & 0.66 & 0.35 & 0.25 & 81.15 & 12.15 & 87.25 & 5984.80 \\
\hline Minimum & 0.94 & 0.14 & 0.21 & 0.43 & 0.17 & 0.09 & 11.00 & 0.55 & 7.45 & 3378.40 \\
\hline $\mathrm{CV}(\%)$ & 16.60 & 24.23 & 16.79 & 13.76 & 20.99 & 32.40 & 48.85 & 57.63 & 62.94 & 18.63 \\
\hline
\end{tabular}

${ }^{1} \mathrm{n}=$ three samples collected from 0-0.10 m depth. ${ }^{2} \mathrm{n}=15$ samples. BD - Soil bulk density, Ma - macroporosity, Mi - microporosity, TP total porosity, FC - field capacity (at the matric potential $-10 \mathrm{kPa}$ ), PWP - permanent wilting point (at the matric potential $-1,500 \mathrm{kPa}$ ). 
and $1302 \mathrm{~kg} \mathrm{ha}^{-1}$ for the cultivars IPR 126, FAPA 2 and FUNDACEPFAPA 43, respectively.

Pearson's correlations analysis showed that the values of the $\mathrm{pH}$, calcium and magnesium contents, as well as the base saturation of the oxisols, were determinants of white oat dry mass production (Table 3 ). The exchangeable cations like calcium which is constituent of plant cell walls and cell division, whereas magnesium participate in physiological processes like enzymatic activation, photosynthesis and DNA and RNA synthesis and also is a component of chlorophyll molecule (Taiz \& Zeiger, 2013). In addition, calcium and magnesium uptake by oats is impaired by low $\mathrm{pH}$ and high aluminium concentrations (Silva et al., 2013). The authors also report that the uptake of magnesium and calcium by white oats is affected by increased aluminium in the solution. In a Latossolo Vermelho/Oxisol from southern Brazil, Castro \& Crusciol (2013) observed increases in shoot dry matter yield of oats with the use of surface liming.

The potassium contents of the oxisols were positively correlated with white oat dry mass production (Table 3 ). This correlation was similar to that verified by Melo et al. (2011) in the black oats. Rozane et al. (2008) observed that the omission of potassium from a nutrient solution resulted in lower dry mass production of black oats, and the authors observed an even greater accumulation of calcium and magnesium in plants with full potassium treatment. In soils with reduced $\mathrm{pH}$, the potassium uptake by oats can be impaired (Harper \& Balke 1981).
The white oat dry mass production was positively correlated with the potential CEC of the oxisols (Table 3). This correlation was expected, since the base cations calcium, magnesium and potassium were also positively correlated with oat dry mass production. In sandy soils of the Eastern Region of Polônia, Usowicz \& Lipiec (2017) demonstrated that the soil potential CEC and oat grain production were positively correlated.

Soil physical attributes, the microporosity and total porosity of the oxisols were positively correlated with white oat dry mass production (Table 3 ). The water and gas flows and availability in the soil depend on soil porosity, and those factors may affect the crop yield. In New Zealand clayey soils, Sojka et al. (1997) observed higher oat dry mass production in soil management systems that presented greater air soil permeability and hydraulic conductivity. The limitation of soil water infiltration is one of the variables that most often limits grain yield (Santi et al., 2012).

The volumetric water contents at field capacity and at the permanent wilting point correlated positively with the oat dry mass production (Table 3). With regard to soil moisture, oats require more moisture than any other winter cereal (Castro et al., 2012). In a study with different winter cereals (wheat, barley and oat), Usowicz \& Lipiec (2017) observed that cereal production were more strongly positively correlated with the soil water content. In soils with fast water content release like sandy soils, cereal production depends not only on the total amount of rainfall

Table 3: Pearson correlations between soil attributes and shoot dry matter of white oat cultivar IPR Afrodite cultivated in five Oxisols in Paraná ( $\mathrm{n}=15)$

\begin{tabular}{lllc}
\hline \multirow{2}{*}{ Attributes } & \multicolumn{1}{c}{ Correlation } \\
\cline { 2 - 3 } & $\mathbf{r}$ & Classification & Probability \\
\hline Available phosphorus content $\left(\mathrm{mg} \mathrm{dm}^{-3}\right)$ & -0.183 & very weak & 0.512 \\
Total organic carbon $\left(\mathrm{g} \mathrm{dm}^{-3}\right)$ & 0.364 & weak & 0.182 \\
Aluminium $\left(\mathrm{cmol}_{\mathrm{c}} \mathrm{dm}^{-3}\right)$ & -0.448 & moderate & 0.020 \\
$\mathrm{pH}\left(\mathrm{CaCl}_{2}\right)$ & $0.594^{*}$ & moderate & 0.094 \\
Potential acidity $\left(\mathrm{cmol}_{\mathrm{c}} \mathrm{dm}^{-3}\right)$ & 0.006 & very weak & 0.984 \\
Exchangeable calcium content $\left(\mathrm{cmol}_{\mathrm{c}} \mathrm{dm}^{-3}\right)$ & $0.745^{* *}$ & strong & 0.001 \\
Exchangeable magnesium content $\left(\mathrm{cmol}_{\mathrm{c}} \mathrm{dm}^{-3}\right)$ & $0.807^{* *}$ & strong & 0.000 \\
Available potassium content $\left(\mathrm{cmol}_{\mathrm{c}} \mathrm{dm}^{-3}\right)$ & $0.555^{*}$ & moderate & 0.032 \\
Potential CEC $\left(\mathrm{cmol}_{\mathrm{c}} \mathrm{dm}^{-3}\right)$ & $0.564^{*}$ & moderate & 0.029 \\
Base saturation $(\%)$ & $0.565^{*}$ & moderate & 0.028 \\
Bulk density $\left(\mathrm{g} \mathrm{cm}^{-3}\right)$ & -0.487 & moderate & 0.066 \\
Macroporosity $\left(\mathrm{cm}^{3} \mathrm{~cm}^{-3}\right)$ & 0.168 & very weak & 0.550 \\
Microporosity $\left(\mathrm{cm}^{3} \mathrm{~cm}^{-3}\right)$ & $0.692^{* *}$ & strong & 0.004 \\
Total porosity $\left(\mathrm{cm}^{3} \mathrm{~cm}^{-3}\right)$ & $0.534^{*}$ & moderate & 0.040 \\
Field capacity $\left(\mathrm{cm}^{3} \mathrm{~cm}^{-3}\right)$ & $0.702^{* *}$ & strong & 0.004 \\
Permanent wilting point $\left(\mathrm{cm}^{3} \mathrm{~cm}^{-3}\right)$ & $0.678^{* *}$ & moderate & 0.005 \\
Clay $($ dag kg-1) & $0.631^{*}$ & moderate & 0.012 \\
Silt $\left(\right.$ dag kg $\left.^{-1}\right)$ & 0.437 & moderate & 0.103 \\
Sand $\left(\right.$ dag kg $\left.^{-1}\right)$ & $-0.612^{*}$ & moderate & 0.015 \\
\hline
\end{tabular}

${ }^{*},{ }^{* *}$ significant values at $5 \%$ and $1 \%$ by the F-test, respectively.

Rev. Ceres, Viçosa, v. 68, n.5, p. 441-452, sep/oct, 2021 
but also on its temporal distribution relative to the plant growth stage (Lipiec \& Usowicz, 2018).

The permanent wilting point of the oxisols was not negatively correlated with white oat dry mass production. In a study evaluating black oat root development and water uptake, Ehlers et al. (1987) observed a reduction in oat root development with increasing soil water tensionand stopped at approximately $1,900 \mathrm{kPa}$. Considering the permanent wilting point of $1,500 \mathrm{kPa}$ in the present study, the oat crop possibly absorbed water at higher pressure.

The clay content of the oxisols was positively correlated with white oat dry mass production, whereas the sand content was negatively correlated (Table 3). These results are attributed to the influence of the clay and sand particles because the increase in the clay content in the soil increased the bases (calcium, magnesium and potassium) and the volumetric content of water in the soil, factors that condition the oat dry mass productionSoil attributes that were significant by Pearson's correlation were analysed using a factor analysis, where the data, cumulatively, showed that components 1 and 2 explained $90.442 \%$ of the existing variance (Table 4 ).

The chemical attributes of the oxisols, such as the $\mathrm{K}$ and $\mathrm{T}$, along with the physical attributes, were the ones best explained by factor 1 . The chemical attributes $\mathrm{pH}$, $\mathrm{Ca}, \mathrm{Mg}$ and base saturation were better explained by factor 2 (Table 4).

These results reflect that the attributes of the oxisols related to factor 1 were more intrinsic; that is, they did not present significant changes with liming, whereas the attributes related to factor 2 were more extrinsic with liming. Thus, oat production could be increased with an increase in the soil attributes of factor 2.

The utilization of soil potassium depends on the texture and may be higher in sandy soils due to the lower buffering capacity of K, as expressed by the CEC (Medeiros et al., 2010; Maluf et al., 2015). The soil porous system is mainly altered by machine traffic, a fact that did non-existen in this study. In a study evaluating the growth of maize roots under controlled machine traffic, Mazurana et al. (2013) observed that microporosity is little influenced by winter cover crops and machine traffic and is more influenced by intrinsic characteristics.

The availability of water to plants depends on soil intrinsic factors, such as their structure, texture, type and clay content. The water holding capacity soil profile is intrinsic to its matrix and does not depend on the plants (Petry et al., 2007).

Considering all the soil attributes evaluated, the ones that jointly best explained the oat dry matter production by factor analysis were the potassium content, CEC, microporosity, total porosity, field capacity, permanent wilting point, clay and sand contents, $\mathrm{pH}$, calcium, magnesium and base saturation, and the following multiple linear regression equation was fitted:

$\mathrm{DM}=2.2221 .54+(7.26 \cdot(0.896 \cdot \mathrm{K}+0.833 \cdot \mathrm{CEC}+0.868 \cdot \mathrm{Mi}+$ $0.978 \cdot \mathrm{TP}+0.912 \cdot \mathrm{FC}+0.957 \cdot \mathrm{PWP}+0.957 \cdot \mathrm{Clay}-$ $0.962 \cdot$ Sand $))+(32.61 \cdot(0.956 \cdot \mathrm{pH}+0.748 \cdot \mathrm{Ca}+0.825 \cdot \mathrm{Mg}+$ $0.973 \cdot \mathrm{V} \%)) \mathrm{R}^{2}=0.61^{* *}$

where DM is the white oat dry mass $\left(\mathrm{kg} \mathrm{ha}^{-1}\right), \mathrm{K}$ is the available potassium content $\left(\mathrm{cmol}_{\mathrm{c}} \mathrm{dm}^{-3}\right), \mathrm{CEC}$ is the potential cation exchange capacity $\left(\mathrm{cmol}_{\mathrm{c}} \mathrm{dm}^{-3}\right)$, Mi is the microporosity $\left(\mathrm{cm}^{3} \mathrm{~cm}^{-3}\right), \mathrm{TP}$ is the total porosity $\left(\mathrm{cm}^{3} \mathrm{~cm}^{-}\right.$ $\left.{ }^{3}\right), \mathrm{FC}$ is the field capacity $\left(\mathrm{cm}^{3} \mathrm{~cm}^{-3}\right), \mathrm{PWP}$ is the permanent wilting point $\left(\mathrm{cm}^{3} \mathrm{~cm}^{-3}\right)$, Clay is the clay content (dag kg$\left.{ }^{1}\right)$, Sand is the sand content $\left(\mathrm{dag} \mathrm{kg}^{-1}\right), \mathrm{Ca}$ is calcium ( $\mathrm{cmol}_{\mathrm{c}}$ $\left.\mathrm{dm}^{-3}\right), \mathrm{Mg}$ is magnesium $\left(\mathrm{cmol}_{\mathrm{c}} \mathrm{dm}^{-3}\right)$, and $\mathrm{V} \%$ is base saturation (\%).

Obtaining a set of soil attributes that explains $61 \%$ shoot dry mass of white oat production is satisfactory because the yield of any crop is the result of the interactivity of climatic, plant and soil factors.

The model was tested to predict the shoot dry mass of white oat cultivar IPR Afrodite production in the next crop, after identifying and removing two outliers, and the model was thereby found to have a predictive accuracy of $74 \%$ (Figure 4).

The chemical and physical attributes of oxisols at the 0-0.10 m layer were therefore used to develop a model capable of estimating with good accuracy the dry mass production of white oats.

Table 4: Eigenvalues of factors, variance components and total variance explained by the chemical and physical attributes of the oxisols

\begin{tabular}{lcc}
\hline \multirow{2}{*}{ Variance components } & \multicolumn{2}{c}{ Factors } \\
\cline { 2 - 3 } & $\mathbf{1}$ & $\mathbf{2}$ \\
\hline Eigenvalues & 6.893 & 2.146 \\
Proportion (\%) & 68.938 & 21.459 \\
Cumulative proportion (\%) & 68.938 & 90.387 \\
\hline Variables & Correlation with the factors \\
\hline $\mathrm{pH}$ & -0.077 & $0.956^{*}$ \\
$\mathrm{Ca}$ & 0.560 & $0.748^{*}$ \\
$\mathrm{Mg}$ & 0.515 & $0.825^{*}$ \\
$\mathrm{~K}$ & $0.896^{*}$ & 0.057 \\
$\mathrm{~T}$ & $0.833^{*}$ & 0.088 \\
$\mathrm{~V} \%$ & 0.043 & $0.973^{*}$ \\
$\mathrm{Mi}$ & $0.868^{*}$ & 0.366 \\
$\mathrm{TP}$ & $0.978^{*}$ & 0.030 \\
FC & $0.912^{*}$ & 0.326 \\
$\mathrm{PWP}$ & $0.957^{*}$ & 0.245 \\
Clay & $0.957^{*}$ & 0.169 \\
Sand & $-0.912^{*}$ & -0.155 \\
\hline
\end{tabular}

Bartlett's test of sphericity $=9.72^{10-41}$ and Kaiser-Meyer-Olkin $(\mathrm{KMO})$ test $=0.664 .{ }^{*}$ Traits with higher factor loads (scores) selected within each factor. 


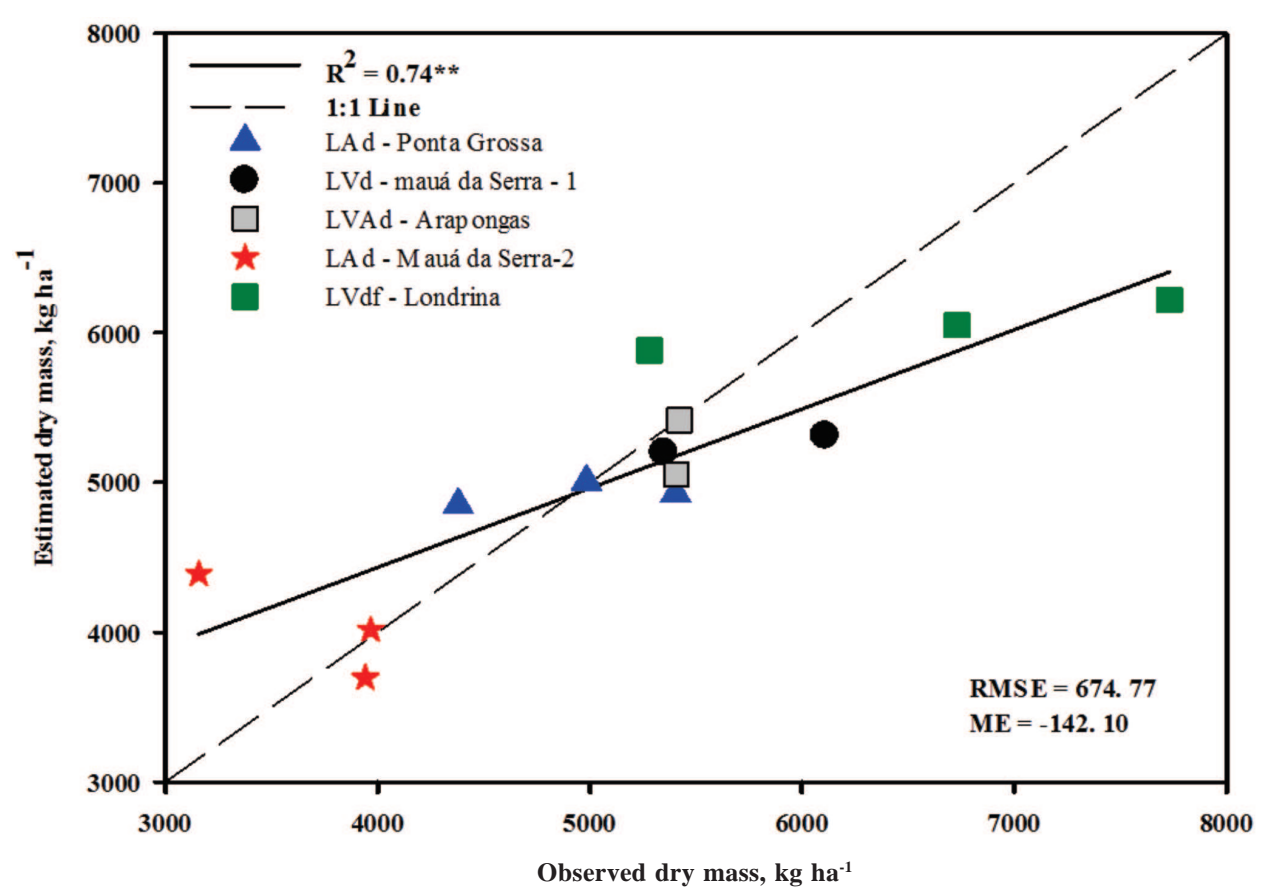

Figure 4: Regression of estimated and observed white oat dry mass production.

\section{CONCLUSIONS}

The soil chemical attributes $\mathrm{pH}$ in $\mathrm{CaCl}_{2}, \mathrm{Ca}$ content, $\mathrm{Mg}$ content, $\mathrm{K}$ content, potential cation exchange capacity, and base saturation and soil physical attributes microporosity,total porosity, field capacity, permanent wilting point (PWP) and clay and sand contents of the Oxisols most affected white oat shoot dry mass production.

The soil chemical attributes $\mathrm{pH}$ in $\mathrm{CaCl}_{2}, \mathrm{Ca}$ content and $\mathrm{Mg}$ content, in addition to the base saturation of the Oxisols, are extrinsic properties that are positively altered with surface liming, thereby increasing white oat dry mass production.

The multiple regression model that was composed based on factor analysis was efficient for predicting dry mass production of white oats in five oxisols managed with surface liming.

\section{REFERENCES}

Affholder F, Poeydebat C, Corbeels M, Scopel E \& Tittonell P (2013) The yield gap of major food crops in family agriculture in the tropics: Assessment and analysis through field surveys and modelling. Field Crops Research, 143:106-18.

Andognini J, Albuquerque JA, Warmling MT, Teles JS \& Da Silva GB (2020) Soil compaction effect on black oat yield in Santa Catarina, Brazil. Revista Brasileira de Ciência do Solo, 44:1-16.

Araujo-Junior CF \& Miyazawa M (2012) Funções de pedotransferência para a curva de compactação de seis Latossolos do Estado do Paraná. In: Congresso Brasileiro de Engenharia Agrícola - CONBEA, Londrina. Proceedings, Sociedade Brasileira de Engenharia Agrícola. p.176-184.
Balbinot Junior AA, Franchini JC, Debiasi H, Coelho AE, Sapucay MJLC, Bratti F \& Locatelli JL (2020) Performance of soybean grown in succession to black oat and wheat. Pesquisa Agropecuária Brasileira, 55:19.

Bertoni J \& Lombardi Neto F (2010) Conservação do solo. $7^{\text {th }}$ ed. São Paulo, Ícone. 355p.

Bhering SB \& Santos HG (2008) Mapa de Solos do Estado do Paraná. Rio de Janeiro, Embrapa Florestas, Embrapa Solos, Instituto Agronômico do Paraná. 32p.

Bordin I, Silva N dos S, Silva TRB da, Santos JB dos, Gil LG, Canalli LT dos S, Hojo RH \& Llanillo RF (2020) Soybean cropping systems on sandy soil of the Caiuá Sandstone formation in Northwestern Paraná, Brasil. Semina: Ciências Agrárias, 41:2061-2070.

Caires EF, Garbuio FJ, Alleoni LRF \& Cambri MA (2006) Calagem superficial e cobertura de aveia preta antecedendo os cultivos de milho e soja em sistema plantio direto. Revista Brasileira de Ciência do Solo, 30:87-98.

Carvalho EJM, Figueredo MS \& Costa LM (1999) Comportamento físico-hídrico de um Podzólico Vermelho-Amarelo câmbico fase terraço sob diferentes sistemas de manejo. Pesquisa Agropecuária Brasileira, 34:57-265.

Castro GSA, Costa CHM \& Neto JF (2012) Ecofisiologia da aveia branca. Scientia Agraria Paranaensis, 11:1-15.

Castro GSA \& Crusciol CAC (2013). Effects of superficial liming and silicate application on soil fertility and crop yield under rotation. Geoderma, 196:234-242.

Day PR (1965) Particle fractionation and particle-size analysis. In: Black CA (Ed.) Methods of soil analysis. Madison, American Society of Agronomy. p.545-566.

Demétrio JV, da Costa ACT \& de Oliveira OS (2012) Produção de biomassa de cultivares de aveia sob diferentes manejos de corte. Pesquisa Agropecuária Tropical, 42:198-205.

Derpsch R, Sidiras N \& Heinzmann FX (1985) Manejo do solo com coberturas verdes de inverno. Pesquisa Agropecuária Brasileira, 20:761-773. 
Diehl RC, Miyazawa M \& Takahashi HW (2008) Compostos orgânicos hidrossolúveis de resíduos vegetais e seus efeitos nos atributos químicos do solo. Revista Brasileira de Ciência do Solo, 32:2653-2659.

Ehlers W, Khosla BK, Kopke U, Stulpnagel R, Bohm W \& Baeumer K (1987) Tillage effects on root development, water uptake and growth of oats. Soil \& Tillage Research, 1:19-34.

Embrapa - Empresa Brasileira de Pesquisa Agropecuária (2018) Sistema Brasileiro de Classificação de Solos. $5^{\text {th }}$ ed. Rio de Janeiro, Embrapa Solos. 592p.

Flint LE \& Flint A (2002) Porosity. In: Dane JH \& Topp GC (Eds.) Methods of soil analysis: physical methods. Madison, Soil Science Society of America. p.680-683.

Grohmann F \& Van Raij B (1977) Dispersão mecânica e prétratamento para análise granulométrica de Latossolos argilosos. Revista Brasileira de Ciência do Solo, 1:52-53.

Grossman RB \& Reinsch TG (2002) Bulk density and linear extensibility. In: Dane JH \& Topp GC (Eds.) Methods of Soil Analysis - Part 4: Physical Methods. Madison, Soil Science Society of America. p.201-225.

Gujarati DN \& Porter DC (2011) Econometria Básica. 5a ed. Porto Alegre, AMGH. 924p.

Harper JR \& Balke NE (1981) Characterization of the inhibition of $\mathrm{K}+$ absorption in oat roots by salicylic Acid. Plant physiology, 68:1349-1353

Hoogmoed WB \& Derpsch R (1985) Chisel ploughing as an alternative tillage system in Paraná, Brazil. Soil \& Tillage Research, 6:53-67.

IAPAR - Instituto Agronômico do Paraná (2019) Dados diários de Londrina 2015. Available at: http://www.iapar.br/modules/ conteudo/conteudo.php?conteudo $=2085$. Accessed on: January $10^{\text {th }}, 2019$.

Junges AH \& Fontana DC (2011) Modelo agrometeorológicoespectral de estimativa de rendimento de grãos de trigo no Rio Grande do Sul. Revista Ceres, 58:09-16.

Lipiec J \& Usowicz B (2018) Spatial relationships among cereal yields and selected soil physical and chemical properties. Science of the Total Environment, 633:1579-1590.

Maluf HJGM, Soares BEM, da Silva IR, Neves JCL \& Silva MFO (2015) Disponibilidade e recuperação de nutrientes de resíduos culturais em solo com diferentes texturas. Revista Brasileira de Ciência do Solo, 39:1690-1702.

Marolli A, da Silva JAG, Scremin OB, Mantai RD, Trautmann APB, Mamann ATW, Carbonera R, Kraisig AR, Krüger CAMB \& Arenhardt EG (2017) A Proposal of Oat Productivity Simulation by Meteorological Elements, Growth Regulator and Nitrogen. American Journal of Plant Sciences, 08: 2101-18.

Mazurana M, Fink JR, Silveira VH, Levien R, Zulpo L \& Brezolin D (2013) Propriedades físicas do solo e crescimento de raízes de milho em um argissolo vermelho sob tráfego controlado de máquinas. Revista Brasileira de Ciência do Solo, 37:1185-1195.

Medeiros JS, Oliveira FHT, Arruda JA, Vieira MS \& Fontes MPF (2010) Eficiência de extratores de potássio disponível em solos do Estado da Paraíba com graus de desenvolvimento pedogenético diferentes. Revista Brasileira de Ciência do Solo, 34:183-194.

Melo AV, Galvão JCC, Braun H, Santos MM, Coimbra RR, Silva RR \& Reis WF (2011) Extração de nutrientes e produção de biomassa de aveia-preta cultivada em solo submetido a dezoito anos de adubação orgânica e mineral. Semina:Ciências Agrárias, $32: 411-420$.
Miyazawa M \& Barbosa GMC (2011) Efeitos da agitação mecânica e matéria orgânica na análise granulométrica do solo. Revista Brasileira de Engenharia Agrícola e Ambiental, 15:680-685.

Muzilli O (2002) Manejo da matéria orgânica no sistema plantio direto: a experiência no Estado do Paraná. Informações Agronômicas, 10:6-10.

Nitsche PR, Caramori PH, Ricce WS \& Pinto LFD (2019) Atlas climático do Estado do Paraná. Available at: http://www.iapar.br/ arquivos/File/zip_pdf/AtlasClimaticoPR.pdf. Accessed on: June $10^{\text {th }}, 2019$.

Oliveira E, Assmann AL, Assmann TS \& Mezzadri F (2018) Estado da arte e estudos de caso em Sistemas Integrados de Produção Agropecuária no Sul do Brasil. In: Souza ED, Silva FD, Assmann TS, Carneiro MA, Carvalho PCF \& Paulinho HB (Eds.) Sistemas Integrados de Produção Agropecuária no Brasil. Tubarão, Copiart. p.239-254.

Oliveira EL \& Pavan MA (1996) Control of soil acidity in notillage system for soybean production. Soil \& Tillage Research, $38: 47-57$

Pauletti V \& Motta ACV (2017) Manual de adubação e calagem para o estado do Paraná. $1^{\text {st }}$ ed. Curitiba, Sociedade Brasileira de Ciência do Solo/Núcleo Estadual Paraná. 482p.

Pavan MA, Bloch MF, Zempulski HD, Miyazawa M \& Zocoler DC (1992) Manual de análise química do solo e controle de qualidade. Londrina, Instituto Agronômico do Paraná. 40p. (Circular, 76)

Petry MT, Zimmermann FL, Carlesso R, Michelon CJ \& Kunz, JH (2007) Disponibilidade de água do solo ao milho cultivado sob sistemas de semeadura direta e preparo convencional. Revista Brasileira de Ciência do Solo, 31:531-539.

Riede CR, Garbuglio DD, Machado ACZ, Póla JN, Carvalhal R \& Arruda KMA (2015) IPR AFRODITE - new oat cultivar with nematode resistance. Crop Breeding and Applied Biotechnology, $15: 278-281$

Rozane DE, Prado RM \& Romualdo LM (2008) Deficiências de macronutrientes no estado nutricional da aveia- preta cultivar comum. Científica, 36:116-122.

Santi AL, Amado TJC, Cherubin MR, Martin TN, Pires JL, Flora LPD \& Basso CJ (2012) Análise de componentes principais de atributos químicos e físicos do solo limitantes á produtividade de grãos. Pesquisa Agropecuária Brasileira, 47:1346-1357.

Silva JAG, Reis CES, Crestani M, Souza RO, Oliveira AC \& Carvalho FIF (2013) Absorção de cálcio e magnésio por cultivares de aveia submetidas a níveis de toxidez por alumínio. Semina: Ciências Agrárias, 34:3563-3576.

Sojka RE, Horne DJ, Ross CW \& Baker CJ (1997) Subsoiling and surface tillage effects on soil physical properties and forage oat stand and yield. Soil \& Tillage Research, 40:125-144.

Soratto RP \& Crusciol CAC (2008) Nutrição e produtividade de grãos da aveia-preta em função da aplicação de calcário e gesso em superfície na implantação do sistema plantio direto. Revista Brasileira de Ciência do Solo, 32:715-725.

Sorrells ME \& Simmons SR (1992) Influence of environmenton the development and adaptation of oat. In: Marshall HG \& Sorrells ME (Eds.) Oat science and technology. Madison, WI. p.115-163.

Stone LF, Ferreira EPB, Didonet AD, Heinemann AB \& Oliveira JP (2013) Correlação entre a produtividade do feijoeiro no sistema de produção orgânica e atributos do solo. Revista Brasileira de Engenharia Agrícola e Ambiental, 17:19-25.

Taiz L \& Zeiger E (2013) Fisiologia vegetal. $5^{\text {th }}$ ed. Porto Alegre, Artmed. 954p.

Rev. Ceres, Viçosa, v. 68, n.5, p. 441-452, sep/oct, 2021 
Topp GC \& Ferré TPA (2002) The soil solution phase. In: Dane JH \& Topp GC (Eds.) Methods of soil analysis - part 4: Physical Methods. Madison, Soil Science Society of America. p.4171074 .

Usowicz B \& Lipiec J (2017) Spatial variability of soil properties and cereal yield in a cultivated field on sandy soil. Soil \& Tillage Research, 174:241-250.

Vezzani FM \& Mielniczuk J (2009) Uma visão sobre a qualidade do solo. Revista Brasileira de Ciência do Solo, 33:743-755.

Vieira RCB, Bayer C, Fontoura SMV, Anghinoni I, Ernani PR \& Moraes RP (2013) Critérios de calagem e teores críticos de fósforo e potássio em Latossolos sob plantio direto no CentroSul do Paraná. Revista Brasileira de Ciência do Solo, 37:188198.
Vomocil JA (1965) Porosity. In: Blake CA (Ed.) Methods of soil analysis, Madison, American Society of Agronomy. p.299-314.

Walkley A \& Black I (1934) Armstrong an examination of the Degtjareff method for determining soil organic matter, and a proposed modification of the chromic acid titration method. Soil Science, 37:29-38.

Xu X, Nieber JL \& Gupta SC (1992) Compaction Effect on the Gas Diffusion Coefficient in Soils. Soil Science Society of America Journal, 56:1743-1750.

Ziech ARD, Conceição PC, Luchese AV, Balin NM, Candiotto G \& Garmus TG (2015) Proteção do solo por plantas de cobertura de ciclo hibernal na região Sul do Brasil. Pesquisa Agropecuária Brasileira, 50:374-382. 